\title{
ENTREPRENEURSHIP EDUCATION IN HUMANITIES AND SOCIAL SCIENCES: ARE STUDENTS QUALIFIED TO START A BUSINESS?
}

\author{
José Luis Vázquez-Burgete ${ }^{1}$, Ana Lanero $^{2}$, Agota Giedre Raisiene $^{3}$, María Purificación García ${ }^{4}$
}

${ }^{1,2,4}$ University of León, Campus de Veganzana s/n, 24071 León, Spain

${ }^{3}$ Mykolas Romeris University, Ateities g. 20, LT-08303 Vilnius, Lithuania

E-mails: ${ }^{1}$ jose-luis.vazquez@unileon.es; ${ }^{2}$ ana.lanero@unileon.es (corresponding author);

3agotar@mruni.eu; ${ }^{3}$ mpgarm@unileon.es

Received 8 December 2011; accepted 30 December 2011

\begin{abstract}
Over the last decade, entrepreneurship education has been acknowledged by European governments as a promising way to improve the work insertion of young people and, at the same time, contribute to general purposes of social and economic welfare. Particularly, social entrepreneurship is considered an emerging area of growth which provides the opportunity to make a difference in global community contexts. From this view, this paper proposes a model of entrepreneurship education based on the European Framework on Key Competences for Lifelong Learning to analyze the involvement of universities in related actions as perceived by students within Humanities and Social Sciences. Data was collected from a total sample of 448 students at two Spanish universities. Descriptive analysis was used to examine the development of entrepreneurship-related knowledge, skills and attitudes among students and its implications for labor insertion of future graduates in Humanities and Social contexts. Further conclusions of the study are discussed.
\end{abstract}

Keywords: social entrepreneurship, entrepreneurship education, entrepreneurship competence, European Higher Education Area (EHEA), Social Sciences, Humanities, entrepreneurship education in Spain.

JEL Classification: M54, I23, I25.

\section{VERSLUMO UGDYMAS HUMANITARINIŲ IR SOCIALINIŲ MOKSLŲ STUDIJOSE: AR STUDENTAI YRA PASIRENGĘ PRADÉTI SAVO VERSLĄ?}

\author{
José Luis Vázquez-Burgete ${ }^{1}$, Ana Lanero ${ }^{2}$, Agota Giedrè Raišiene் ${ }^{3}$, María Purificación García ${ }^{4}$ \\ 1, 2, ${ }^{4}$ Leono universitetas, Campus de Veganzana s/n, 24071 Leonas, Ispanija \\ ${ }^{3}$ Mykolo Romerio universitetas, Ateities g. 20, LT-08303 Vilnius, Lietuva \\ El.paštas: ${ }^{1}$ jose-luis.vazquez@unileon.es; ${ }^{2}$ ana.lanero@unileon.es; \\ 3agotar@mruni.eu; ${ }^{4}$ mpgarm@unileon.es
}

Iteikta 2011-12-8; priimta 2011-12-30

Santrauka. Pastarąji dešimtmetị verslumo ugdymas Europos šalių vyriausybių pripažintas kaip perspektyvus būdas, galintis padèti pagerinti jaunų žmonių įsitraukimą i darbo rinką ir paskatinti ES socialinès bei ekonominès gerovès augimą. Tad socialinio verslumo vystymas tampa itin aktualus, siekiant pokyčių pasaulio visuomenès kontekste. Remdamiesi šiuo požiūriu ir mokymosi visą gyvenimą gairèmis, straipsnio autoriai domisi, kokią įtaką studijos universitete turi formuojant humanitarinių 
ir socialinių mokslų studentų verslumo kompetencijas. Pristatomi empirinio tyrimo, kuriame dalyvavo 448 dviejų Ispanijos universitetų absolventai, rezultatai. Remiantis aprašomosios statistikos metodais analizuojama, kokių žinių ir igūdžių, nuostatų, leidžiančių komercializuoti būsimus savo darbo rezultatus, yra ịgiję studentai, diskutuojama, kiek verslumo kompetencijos gali padèti įsitraukimo ị darbo rinką aspektu. Tyrimo rezultatai rodo, kad ị verslo aplinką geriau pasiruošę integruotis socialinių mokslų krypties absolventai, o humanitarinių studijų krypties atstovai, nors ir pasižymi teigiamomis nuostatomis asmeninio verslumo ugdymo požiūriu, stokoja tam būtinų žinių ir gebejjimų.

Reikšminiai žodžiai: socialinis verslumas, verslumo ugdymas, verslumo kompetencijos, Europos aukštojo mokslo erdve, socialiniai mokslai, humanitariniai mokslai, verslumo ugdymas Ispanijoje.

\section{Introduction}

In the last few years, adaptation of university systems to the requirements of the European Higher Education Area (EHEA) are entailing significant transformations in surrounding countries, in an effort to deliver a better response to the social needs and expectations frequently assigned to these institutions. In this respect, it has been traditionally assumed that the educational level acquired must qualify college students to practice a professional activity, which in turn must satisfy the demands of human capital required by the productive sector, in order to contribute to socio-economic welfare. Nevertheless, the traditional flow of transactions between higher education and labor market has been proved to be insufficient in contemporary occidental societies, since unemployment, flexibility and over-qualification are considered the more representative descriptors of young people's work insertion over the last decade in Europe (Eurostat 2009; García-Montalvo, Peiró 2009; OECD 2009a, 2009b).

For this reason, different academics and researchers agree that European universities face the challenge of orienting their academic programs to new social demands (Flavián, Lozano 2004; Michavila 2009; Zabalda 2009), in an attempt to close the gap between students' acquired knowledge and labor market exigencies, and provide full coverage of the needs of all university users and, by extension, those of society. Looking for this purpose, entrepreneurship can be seen as a promising option of work insertion and professional development of recent university graduates, at the service of broader objectives of sustainable socio-economic welfare.

Not in vain, in the context of the wide-ranging social and economic changes that have been occurring in industrialized countries over recent decades, new, small enterprises have become a key element in creating employment, innovation and social welfare in all modern, competitive economies (Acs et al.1994; Thurik 1999; Audretsch et al. 2002; Bosma et al. 2008). This is true to such an extent that encouragement for entrepreneurship is currently at the heart of a host of requirements and public standards in the countries of the European Union (EU), in an effort that has reached out to affect economic, social, educational and employment policies (COM 2000, 2003, 2008).
From this general framework, this paper reviews the concept of entrepreneurial competence and uses it to analyze differences in entrepreneurship education across various Social and Humanities disciplines. In doing that, we first review the guidelines marked by the European common policy with regard to the inclusion of entrepreneurship education as part of the university academic mission and provide a global description of the current state of the matter in European and Spanish institutions of higher education. Next, we review previous literature on entrepreneurship education and define the construct of entrepreneurial competence in terms of specific knowledge, skills and attitudes. According to that, we present an empirical study carried out in two Spanish universities aimed to validate the model proposed and analyze differences in entrepreneurship education between students in the various Social and Humanities areas. Finally, conclusions and implications of the study are discussed.

\section{Entrepreneurship education in the European Higher Education Area}

Encouragement for entrepreneurship education is currently at the heart of a host of political requirements in the countries of the European Union (EU), in an effort to develop a dynamic enterprising culture and foster new firm creation as a source of sustainable competitiveness in the continent (European Parliament 2000; COM 2010). An outcome of that has been the inclusion of the sense of initiative and entrepreneurship in a European Framework on Key Competences for Lifelong Learning (Recommendation 2006). From this view, it is recognized that entrepreneurship acts as a source of personal and professional self-realization, active citizenship and social inclusion for individuals, and that's why entrepreneurial competences should be developed by the end of compulsory school or training, acting as a foundation for further lifelong learning.

In this context, contemporary educational systems are seeing their training missions expanded by the assignment of a further responsibility to provide a socio-economic boost, taking the form of the channeling of future generations of the working population towards entrepreneurial goals in accordance with the new needs of the productive sector. Among all educational institutions, the universities' 
response to this aim is of particular relevance, as they are the principal agents for generating and disseminating specialized knowledge in the context of a social reality in which access to higher education is more and more generalized in developed countries.

In fact, the advisability of promoting entrepreneurial mindsets has extended to the current Bologna Process aimed to build a modern degree structure adapted to the professional profiles required by the current EU society through the establishment of a common European Higher Education Area (EHEA). In this context, the project Tuning educational structures in Europe (González, Wagenaar 2003), devoted to the identification of learning results and desirable competences by thematic area, has included entrepreneurship into the group of systemic transversal competences to be trained along all levels of university higher education.

Despite this political commitment, it is estimated that more than half of university students in Europe do not have access to entrepreneurial education, some differences existing by country (EIDG 2008b). Based on the results of the Survey of entrepreneurship in higher education in Europe, whereas more and more European universities have nowadays some institutional system to disseminate the entrepreneurial culture and give support to new venture creation, entrepreneurship education at a curricular level seems to be influenced by type of institution, years of experience and geographic location.

As expected, European students are more likely to obtain access to entrepreneurial education if they attend a business school or a multidisciplinary institution with a business department. Moreover, the way in which these institutions conduct entrepreneurial education seems to be also different and more elaborate. This can be explained, to some degree, by the fact that these types of institutions have been frontrunners in taking on entrepreneurial education and have therefore worked with it for a longer period of time.

In the same line, time is a factor for implementing entrepreneurship in higher education in Europe, in the sense that the longer an institution has been engaged in entrepreneurial education, the more elaborate it is.

And with regard to geographic location, the survey also points to a difference in access to entrepreneurship education depending on students' country of residence. In general, students in the countries members of the EU have better access to entrepreneurial education than students in nonmember countries or in those which have recently joined the EU. In short, more institutions in Western Europe offer entrepreneurship education compared to Eastern Europe. However, the study doesn't support the assumption that entrepreneurial education in the last countries is less elaborate than in the former. In fact, more institutions in Eastern Europe have a broader model of entrepreneurial education, with more institutions having specialized professors and degrees and providing recognition for achievements in entrepreneurial competences. However, more resources seem to be allocated to entrepreneurship education in Western institutions (EIDG 2008a).

Particularly in Spain, most universities have developed and implemented specific extracurricular actions to give support to potential entrepreneurial initiatives of students, in the form of University-Enterprise foundations, business chairs, spin-off programs or specific institutional programs and centers on entrepreneurship (Directorate General of SME Policy 2006; ANECA 2007). However, the specific impact of those institutional initiatives on the entrepreneurial projections of Spanish graduates seem to be largely unknown, when not some disappointing. In this regard, previous evidence point to the general conclusion that students perceive a scarce consideration of entrepreneurship topics within university programs (Vazquez et al. 2010b), and since academic courses focus on the wage-employment paradigm, the transit through university has a poor effect on the entrepreneurial vocations of students (Vazquez et al. 2009, 2010a).

Further, formal instruction in knowledge and abilities concerning new venture creation is usually limited to academic programs within Business and Economics disciplines, it being practically absent in the curriculum of other academic fields, especially within Humanities and Non-Business Social areas (Vazquez et al. 2010a, 2010b). In these cases, starting a new firm isn't even considered as possible labour option for students, thus there is no awareness of the need of teaching basic entrepreneurial competences in the lecture hall, neither a structured action which allows students to learn them in a regulated way. All of these leads to a lack of receptivity and support to potential entrepreneurial initiatives of students, and lots of brilliant business ideas are forced to oblivion.

This lack of entrepreneurship education in Spanish universities is due to many factors affecting most institutions of higher education in the European countries, particularly the shortage of human and financial resources available for such a kind of pursuits, the rigid organizational structure of higher education institutions, the poor multidisciplinary tradition in the organization of academic programs, and the low motivation and training of the academic staff in entrepreneurship issues (EIDG 2008a, 2008b).

\section{The entrepreneurship competence}

In terms of curricular design, a competence can be defined as a dynamic combination of attributes that together permit a competent performance in a field, as the result of an educational process (González, Wagenaar 2003). From this view, three components are often identified in any competence: i) a conceptual component referred to the acquisition 
of theoretical knowledge about a specific academic field; ii) a procedural component, based on the development of practical skills to apply the conceptual knowledge acquired; and iii) an attitudinal component of learned values, rules and personal attributes (Bolívar 1996; González, Wagenaar 2003; Biggs 2005).

According to this specification, European guidelines remark three fundamental objectives of entrepreneurship teaching programs at the university (EIDG 2008a, COM 2003): i) developing entrepreneurial drive among students and raising their awareness of self-employment as a career option; ii) providing the technical and business skills that are needed to identify and exploit business opportunities, set up a new firm and manage its growth; and iii) promoting the development of personal qualities such as creativity, risk-taking and responsibility.

In the same line, specialized literature is full of attempts for determining the more appropriate contents to be included in entrepreneurship training programs (Cotton, Gibb 1992; Gibb 1993; Hood, Young 1993; Kourilsky 1995; Hisrich, Peters 1998; Smith et al. 2006; Soutaris et al. 2007; Liñán 2007; Pittaway et al. 2009). As a point of reference for all these divergent approaches, the European Framework on Key Competences for Lifelong Learning (Recommendation 2006) specifies the essential knowledge, skills and attitudes related to the sense of initiative and entrepreneurship as a competence, as it is summarized in Table 1. In short, sense of initiative and entrepreneurship is defined as "an individual ability to turn ideas into action. It includes creativity, innovation, and risk taking, as well as the ability to plan and manage projects in order to achieve objectives" (Recommendation 2006: 17).

Beyond that specification, there is a growing awareness of the need of orientating entrepreneurship education according to the needs of students with different academic background (COM 2010; Anderson, Jack 2008; Hofer, Potter 2010). For instance, within Business schools and Economic studies it is assumed that, since many business contents are offered separately (i.e., marketing, management, etc.), entrepreneurship programs should have a very narrow focus, stressing the start-up phase and the growth of small enterprises. Otherwise, experts agree that students in other Social and Humanities areas are usually good in technical aspects and frequently have very strong business ideas, their weaknesses concentrating in the development of specific business knowledge and abilities. From this view, the focus could be on social entrepreneurship as emerging area of growth which provides the opportunity to make a difference in community contexts. However, very little is known about entrepreneurship education in Non-Business Social and Humanities disciplines in European universities. To fill this gap, we next describe an empirical study in two Spanish universities to analyze the perceptions and experiences of students in the various Social disciplines.
Table 1. Entrepreneurship competence

\begin{tabular}{l|l|l}
\hline Knowledge & Skills & Attitudes \\
\hline Available & Proactive project & Initiative \\
opportunities & management & Pro-activeness \\
for personal, & (ability to & Independence \\
professional & plan, organize, & Innovativeness \\
and/or business & manage, lead and & Motivation and \\
activities & delegate, analyze, & determination \\
Workings of the & communicate, & to meet \\
economy & de-brief, evaluate & objectives... \\
Organizational & and record) & \\
opportunities and & Representation & \\
challenges & and negotiation & \\
Ethical position of & Autonomous & \\
enterprises & and collaborative & \\
Fair trade & work & \\
and social & Self-knowledge & \\
entrepreneurship... & Risk taking and & \\
& assessment & \\
\hline
\end{tabular}

Source: Adapted from Recommendation 2006/962/EC of the European Parliament and of the Council (Recommendation 2006)

\section{Sampling and measures}

To make it possible the generalization of results to different institutional contexts, the study sample consisted of undergraduates in Social and Legal Sciences at two Spanish universities: the Complutesian University of Madrid and the University of León. Participants were registered from the final year of their academic programs, in order to provide evidence in undergraduates with enough previous university experience.

The total sample comprised a total of 448 university students, ensuring a criterion of representativeness of $95 \%$ (being $\mathrm{e}= \pm 5 \% ; \mathrm{p}=\mathrm{q}=0.50$ ). By gender, this sample was composed of 337 females $(75.2 \%)$ and 111 males (24.8\%), aged 20 to 47 years old $(\mathrm{M}=23.10, \mathrm{DT}=2.95)$. On the other hand, $21.7 \%$ of respondents indicated a main academic background in Business areas, 21.9\% in Public Administration and Law, $40.8 \%$ in Human Sciences, and $15.6 \%$ in Humanities.

Data collection was based on a procedure of collective voluntary self-administration of a questionnaire in scheduled university classes randomly selected, in the presence of a researcher trained for this end. The questionnaire administered comprised three scales for measuring perceived education of entrepreneurial knowledge, skills and attitudes. Particularly, students were asked to report their academic experiences in learning ten conceptual contents (e.g., "economic contribution of entrepreneurship", "business structure and functioning", "business start-up as a career choice", etc.), eleven skills (e.g., "planning and organization", "management", "risk taking and assessment", etc.), and eight attitudes (e.g., "initiative", "pro-activeness", "creativity", etc.) specified according to the European Framework on Key 
Competences for Lifelong Learning (Recommendation 2006). Respondents were asked to rate the perceived importance assigned to each content in their respective academic programs, on a eleven-point Likert-type scale from 0 (" $n o t$ important at all") to 10 ("very important").

\section{Results}

Once data was collected and processed, we used principal components factor analysis with program SPSS 15.0 to test the construct validity of the variables included in the model.

Prior to performing factor analysis, the suitability of data was assessed. Inspection of the correlation matrix revealed the presence of many coefficients of .30 and above. Also, the Kaiser-Meyer-Oklin value was .946, exceeding the recommended value of .60 (Kaiser 1970, 1974) and the Barlett's Test of Sphericity (Barlett 1954) reached statistical significance, supporting the factorability of the correlation matrix.
Principal components analysis revealed the presence of four factors with eigenvalues exceeding 1 , explaining a $64.88 \%$ of the total variance. Nevertheless, using Catell's scree test (Catell 1966), it was decided to retain only three components for further investigation.

To aid in the interpretation of the three components identified and its discriminant validity, Varimax rotation was performed. The rotated solution presented in Table 2 revealed the multidimensionality of the scales, according to the three dimensions of knowledge, skills and attitudes adopted in the European Framework on Key Competences for Lifelong Learning (Recommendation 2006). In this sense, every item had a loading above .40 in its respective construct, explaining the $22.66 \%, 20.12 \%$, and $18.02 \%$ of the variance. Moreover, all the scales retained were associated to Cronbach's a values of reliability over the recommended .70 (Nunnally 1978).

Table 2. Factor analysis

\begin{tabular}{|c|c|c|c|c|}
\hline & Knowledge & Skills & Attitudes & Mean \\
\hline Business start-up as a career choice & .807 & & & 2.95 \\
\hline Identification of business opportunities & .746 & & & 3.19 \\
\hline Steps to start a business & .755 & & & 2.64 \\
\hline Entrepreneurship local resources & .715 & & & 2.46 \\
\hline Entrepreneurs' work functions & .713 & & & 4.57 \\
\hline Economic contribution of entrepreneurship & .704 & & & 4.30 \\
\hline Business structure and functioning & .702 & & & 4.02 \\
\hline Factors of business success & .690 & & & 4.53 \\
\hline Business models by academic area & .673 & & & 4.18 \\
\hline Social contribution of entrepreneurship & .646 & & & 4.01 \\
\hline Planning and organization abilities & & .742 & & 4.64 \\
\hline Executive abilities and leadership & & 679 & & 4.42 \\
\hline Negotiation abilities & & .670 & & 4.00 \\
\hline Analysis and assessment abilities & & .648 & & 4.93 \\
\hline Management abilities & & .639 & & 4.14 \\
\hline Communication abilities & & .626 & & 5.06 \\
\hline Delegation abilities & & .614 & & 3.55 \\
\hline Team work abilities & & .606 & & 5.46 \\
\hline Risk-taking and assessment & & .562 & & 4.06 \\
\hline Self-knowledge abilities & & .530 & & 3.93 \\
\hline Autonomous work abilities & & .446 & & 3.78 \\
\hline Creativity & & & .756 & 4.16 \\
\hline Independence & & & .753 & 4.45 \\
\hline Innovativeness & & & .750 & 4.14 \\
\hline Pro-activeness & & & .741 & 4.52 \\
\hline Responsibility & & & .739 & 5.68 \\
\hline Initiative & & & .738 & 4.49 \\
\hline Goal self-direction & & & .704 & 4.95 \\
\hline Change flexibility & & & .697 & 4.23 \\
\hline$\%$ Variance explained & $22.66 \%$ & $20.12 \%$ & $18.02 \%$ & \\
\hline Cronbach's a reliability & .921 & .925 & .921 & \\
\hline
\end{tabular}


Table 2 also displays the mean scores obtained by the total sample in the components of the three factors identified. In short, students reported a poor experience of education of entrepreneurship contents, with mean scores under the intermediate 5 in the ten-point scale, with the only exception of communication abilities $(M=5.06)$ and responsibility $(M=5.68)$. In aggregate terms, mean scores were higher for the skills $(M=4.36)$ and attitudes scales $(M=4.58)$ than in the knowledge scale $(M=4.58)$.

In order to analyze the usefulness of the three factors previously identified to discriminate between groups of undergraduate students with different entrepreneurship learning experiences, we performed a Multivariate Analysis of Variance (MANOVA) with academic background as independent variable categorized in the four groups of Business Sciences, Public Administration and Law, Human Sciences, and Humanities.

Results displayed in Table 3 showed a statistically significant difference between students within the academic disciplines considered on the combined dependent variables: $F(9,1075)=16.53, p<.001 ;$ Wilks' Lambda $=.730$; partial eta squared $=.100$.
When the results for the dependent variables were considered separately, differences in perceived teaching of entrepreneurship knowledge $(F(3,444)=34.51$; partial eta squared $=.189)$, skills $(F(3,444)=10.03$; partial eta squared $=.063)$, and attitudes $(F(3,444)=6.45$; partial eta squared $=.042)$ were statistically significant according to a Bonferroni adjusted alpha level of .017 (.05/3).

HSD Tukey post hoc test was performed to analyze the differences between students in specific academic areas more in deep. Statistically significant differences obtained by using an alpha level of .05 are shown in Table 4 . In a general way, students within Business-related areas reported higher scores than their partners in other fields in the three dimensions analyzed. Undergraduates within Public Administration and Law also reported moderated learning experiences of entrepreneurship knowledge, while displayed the lowest mean scores in the attitudes scale. Opposite, Human Sciences students had relatively high perceptions of education of skills and attitudes when compared to other academic fields. Finally, students in Humanities obtained the lowest punctuations in most scales. These results are also summarized in Figure 1.

Table 3. Results from MANOVA

\begin{tabular}{l|l|l|l|l|l}
\hline Variable & Wilks' Lambda & F & Partial Eta Squared & F & Partial Eta Squared \\
\hline Knowledge & \multirow{3}{*}{.730} & \multirow{3}{*}{$16.53^{\star * *}$} & \multirow{2}{*}{.100} & $34.51^{\star}$ & .189 \\
\cline { 1 - 4 } & & & & $10.03^{\star}$ & .063 \\
\hline Attitudes & & & & $6.45^{\star}$ & .042 \\
\hline
\end{tabular}

${ }^{\star} p<.017$ (Bonferroni adjusted alpha level); ${ }^{* * *} p<.001$

Table 4. HSD Tukey post hoc analysis

\begin{tabular}{|c|c|c|c|c|c|}
\hline \multirow{2}{*}{ Dependent variable } & \multicolumn{2}{|l|}{ Independent variable } & \multirow{2}{*}{$\begin{array}{l}\text { Mean dif. } \\
\text { (I-J) }\end{array}$} & \multirow{2}{*}{ Std. Error } & \multirow{2}{*}{ Sig. } \\
\hline & Academic area (I) & Academic area $(\mathrm{J})$ & & & \\
\hline \multirow{5}{*}{ Knowledge } & \multirow{2}{*}{ Business Sciences } & Public Adm. and Law & 1.31 & .255 & .001 \\
\hline & & Human Sciences & 1.59 & .223 & .001 \\
\hline & & Humanities & 2.77 & .279 & .001 \\
\hline & Public Adm. and Law & Humanities & 1.46 & .279 & .001 \\
\hline & Human Sciences & Humanities & 1.17 & .250 & .001 \\
\hline \multirow{3}{*}{ Skills } & \multirow{2}{*}{ Business Sciences } & Public Adm. and Law & 1.02 & .274 & .001 \\
\hline & & Humanities & 1.46 & .300 & .001 \\
\hline & Human Sciences & Humanities & 1.05 & .269 & .001 \\
\hline \multirow[t]{2}{*}{ Attitudes } & Business Sciences & Public Adm. And Law & 1.13 & .292 & .001 \\
\hline & Human Sciences & Public Adm. and Law & 0.98 & .255 & .001 \\
\hline
\end{tabular}




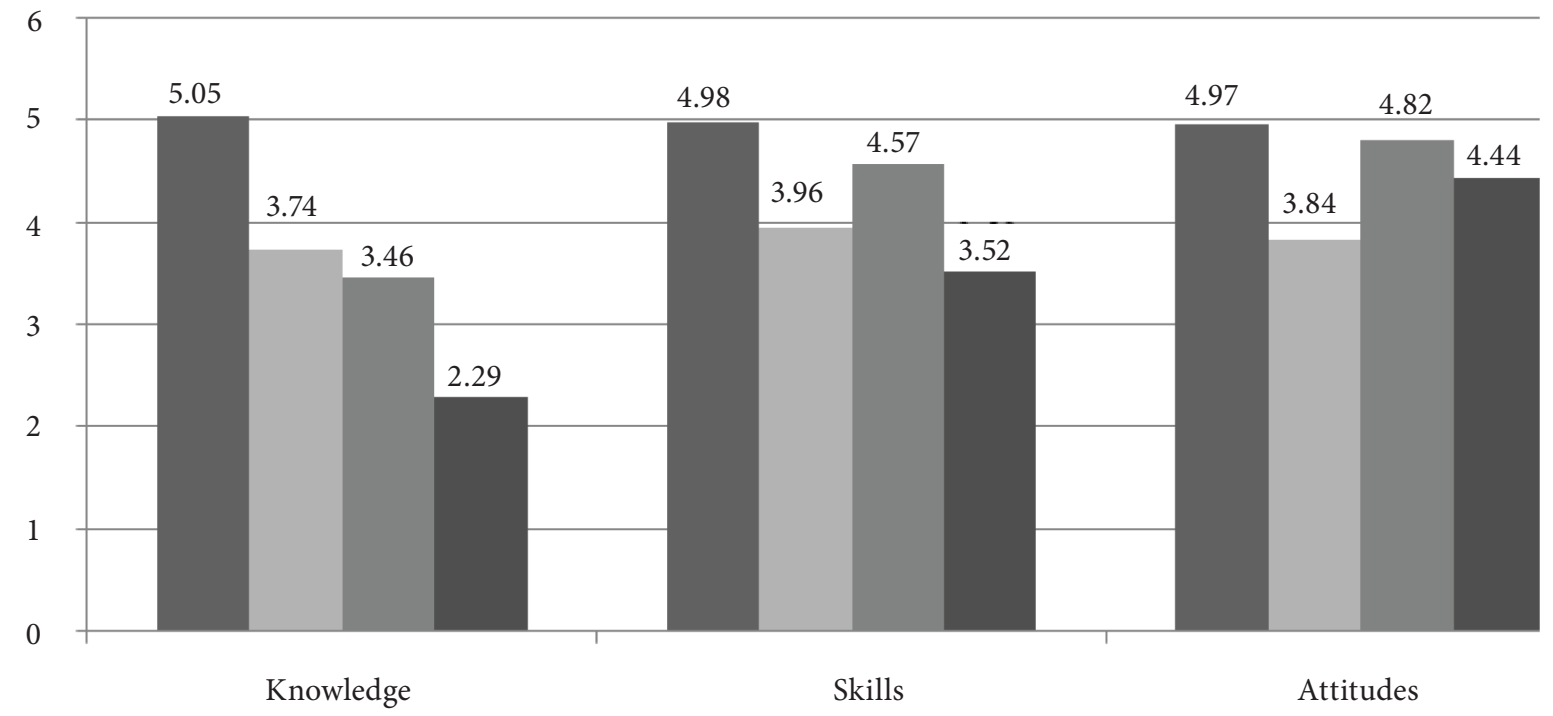

Business Sciences

- Publid Administration and Law

Human Sciences

Humanities

Fig. 1. Mean differences by academic area

\section{Discussion and conclusions}

Entrepreneurial activities act as one main driving force for economic and social development world around. European governments have gained awareness of that in the last decade and a great amount of political measures have been suggested to include entrepreneurship education as part of academic curricula in higher education institutions. However, most high level programs seem to be much more centred on training wage-earner managers or technicians than offering qualified and responsible entrepreneurs and enterprises to society. Given this relatively early stage of development of entrepreneurship education in European universities, this paper has reviewed the construct of entrepreneurship competence to analyze differences in entrepreneurship education between groups of students in the various Social and Humanities disciplines.

In general, the results obtained support the distinction between the three components encompassed by entrepreneurship formal teaching as perceived by students, in terms of the knowledge, skills and attitudes specified in the European Framework on Key Competences for Lifelong Learning (Recommendation 2006). According to that distinction, the climate of change characterizing the current establishment of new degree programs adapted to the EHEA offers an excellent opportunity to work on the design of teaching programs meeting the requirements to encourage entrepreneurship. To serve this curricular planning effort, and by way of suggestions for good practices, the empirical model arising from the work described above sets the adoption of a skill-based teaching model placing the knowledge, skills and attitudes necessary for an adequate development of entrepreneurship at the very heart of any educational intervention.

Furthermore, the structure of entrepreneurship education validated in this work can be taken as a prescriptive framework for evaluating the effectiveness of the programs implemented in European universities, from the personal experiences of undergraduate students with different learning experiences. In this regard, results from the study presented here state a clear underconsideration of entrepreneurship competences in the Spanish universities analyzed, as showed by the poor assessments of the last-year students interviewed in terms of entrepreneurship knowledge, skills and attitudes. However, this picture seems to be different for students with different academic background. As expected, students within Business, followed by Human sciences, reported the most positive perceptions of entrepreneurship education in the university, whereas undergraduates in Humanities disciplines were found to be the less satisfied with the learning experiences provided. From this pattern of results, it can be stressed the lack of attention paid to the entrepreneurial potential of students within non-Business areas, in the sense that promising patterns of non-traditional social business opportunities aren't being recognized as desirable and feasible work options for future graduates.

While the fact that the empirical study reported here was carried out in two different Spanish universities demonstrates that the conclusions drawn from it are sufficiently solid, further studies are required to allow generalization of the results to other Spanish or European institutions. 
It would be even appropriate to consider other models of higher education with the aim of gaining greater precision in the identification of the educational factors determining the effectiveness of academic programs to foster entrepreneurship in the youth.

\section{References}

Acs, Z. J.; Audretsch, D. B.; Evans, D. 1994. Why does the selfemployment rate vary across countries and over time?, in CEPR Discussion Paper No 871. London: Centre for Economic Policy Research.

Anderson, A. R.; Jack, S. L. 2008. Role typologies for enterprising education: the professional artisan?, Journal of Small Business and Enterprise Development 15: 259-273. http://dx.doi.org/10.1108/14626000810871664

ANECA. 2007. Mapa de las actividades de empleo realizadas por las universidades. Madrid: National Agency for Quality Assessment and Accreditation (ANECA).

Audretsch, D. B.; Thurik, R.; Verheul, I.; Wennekers, S. (Eds.). 2002. Entrepreneurship: determinants and policy in a European-U.S. comparison. Boston-Dordrecht: Kluwer academic Publishers.

Barlett, M. S. 1954. A note on the multiplying factors for various chi square approximations, Journal of the Royal Statistical Society 16(B): 296-298.

Biggs, J. 2005. Calidad del aprendizaje universitario. Madrid: Narcea.

Bolívar, A. I. (Ed.). 1996. Jornadas sobre actitudes y educación ambiental. Granada: I.C.E. de la Universidad de Granada.

Bosma, N.; Acs, Z. J.; Autio, E.; Corduras, A.; Levie, J. 2008. Global Entrepreneurship Monitor. 2008 Executive Report. Babson Park, MA-London: Babson College-London Business School.

Catell, R. B. 1966. The scree test for number of factors, Multivariate Behavioral Research 1: 245-276.

http://dx.doi.org/10.1207/s15327906mbr0102_10

COM. 2010(2020). 2010. Europe 2020: a strategy for smart, sustainable and inclusive growth, Communication from the Commission Europe 2020.

COM. 2003. Entrepreneurship in Europe. European Communities, Green Paper, Commission of the European Communities. Available from Internet: http://eur-lex.europa.eu/LexUriServ/ LexUriServ.do?uri=COM:2003:0027:FIN:EN:PDF

COM. 2008. Think Small First - A "Small Business Act" for Europe. Communication from the Commission to the Council, the European Parliament, the European Economic and Social Committee and the Committee of the Regions, European Commission. Available from Internet: http://eur-lex.europa.eu/LexUriServ/LexUriServ. do?uri=COM:2008:0394:FIN:EN:PDF

COM. 2000. Lisbon strategy for growth: towards a green and innovative economy. Brussels: European Commission.

Cotton, J.; Gibb, A. A. 1992. An Evaluation Study of Enterprise Education in the North of England. UK: Durham University Business School.
Directorate General of SME Policy [online]. 2006. Iniciativas emprendedoras en la universidad española. Madrid: Centro de Publicaciones del Ministerio de Industria, Turismo y Comercio. Available from Internet: http://www.ipyme.org/ Publicaciones/EstudioIniciativasEmprendedoras.pdf

EIDG. 2008b. Survey of entrepreneurship in higher education in Europe. Main report, European Commission. Available from Internet: http://ec.europa.eu/enterprise/policies/sme/ files/support_measures/training_education/highedsurvey_en.pdf

EIDG. 2008a. Entrepreneurship in higher education, especially within non-business studies. Final report of the expert group. Brussels: European Commission Enterprise and Industry Directorate General. Available from Internet: http:// ec.europa.eu/enterprise/policies/sme/files/support_measures/training_education/entr_highed_en.pdf.

European Parliament. 2000. Lisbon European Counci, 23 and 24 March 2000 Presidency Conclusions, European Parliament. Available from Internet: http://www.europarl.europa.eu/ summits/lis1_en.htm.

Eurostat. 2009. Eurostat Labour market statistics. Luxembourg: Office for the official publications of the European Union.

Flavián, C.; Lozano, F. J. 2004. Market orientation in public university: a challenger for the Spanish university system, International Review on Public and Non Profit Marketing 1(2): 9-28.

García-Montalvo, J.; Peiró, J. M. 2009. Análisis de la sobrecualificación y la flexibilidad laboral, in Observatorio de Inserción Laboral de los Jóvenes. Valencia: Fundación Bancaja-IVIE.

Gibb, A. A.; Hannon, P. 2006. Towards the Entrepreneurial University, International Journal of Entrepreneurship Education 4: 73.

Gibb, A. A. 1993. The enterprise culture and education, International Small Business Journal 11(3): 11-34. http://dx.doi.org/10.1177/026624269301100301

González, J.; Wagenaar, R. (Eds.). 2003. Tuning Educational Structures in Europe. Bilbao: University of Deusto.

Hisrich, R. D.; Peters, M. P. 1998. Entrepreneurship. 4a edition. Boston, MA: Irwin McGraw-Hill.

Hofer, A.; Potter, J. 2010. Universities, innovation and entrepreneurship: criteria and examples of good practice, in $O E C D$ Local Economic and Employment Development -LEEDWorking Papers. Trento: OECD Publishing.

Hood, J. N.; Young, J. E. 1993. Entrepreneurship's requisite areas of development: a survey of top executives in successful entrepreneurial firms, Journal of Business Venturing 8: 115-135. http://dx.doi.org/10.1016/0883-9026(93)90015-W

Kaiser, H. 1970. A second generation Little Jiffy, Psychometrics 35: 401-415. http://dx.doi.org/10.1007/BF02291817

Kaiser, H. 1974. An index of factorial simplicity, Psychometrics 39: 31-36. http://dx.doi.org/10.1007/BF02291575

Kourilsky, M. L. 1995 Entrepreneurship Education: Opportunity in Search of Curriculum. Kansas City, MO: Center for Entrepreneurial Leadership, Ewing Marion Kauffman Foundation.

Liñán, F. 2007. The role of entrepreneurship education in the entrepreneurial process, in Fayolle, A. (Ed.). Handbook of 
research in entrepreneurship education (Vol. 1). Cheltenham, UK: Edward Elgar Publishing, 230-247.

Michavila, F. 2009. Nuevos contenidos, nuevas metodologías, in Toledo, F.; Michavila, F. (Eds.). Empleo y nuevas titulaciones en Europa. Castellón: Tecnos Universitat Jaume I, 37-51.

Nunnally, J. C. 1978. Psychometric Theory. NY: McGraw-Hill.

OECD. 2009a. Education at a Glance. Paris: Organization for Economic Co-operation and Development (OECD).

OECD. 2009b. Organization for Economic. Paris: Organization for Economic Co-operation and Development (OECD).

Pittaway, L.; Hannon, P.; Gibb, A.; Thompson, J. 2009. Assessment practice in enterprise education, International Journal of Entrepreneurial Behaviour and Research 15: 71-93. http://dx.doi.org/10.1108/13552550910934468

Recommendation 2006/962/EC of the European Parliament and of the Council of 18 December 2006 on key competences for lifelong learning, Official Journal of the European Union L 394: $10-18$.

Smith, A. J.; Collins, L. A.; Hannon, P. D. 2006. Embedding new entrepreneurship programmes in UK higher education institutions. Challenges and considerations, Education and Training 48: 555-567.

http://dx.doi.org/10.1108/00400910610710001
Soutaris, V.; Zerbinati, S.; Al-laham, A. 2007. Do entrepreneurship programmes raise entrepreneurial intention of science and engineering students? The effect of learning, inspiration and resources, Journal of Business Venturing 22: 566-591. http://dx.doi.org/10.1016/j.jbusvent.2006.05.002

Thurik, R. 1999. Entrepreneurship, industrial transformation and growth, in Libercap, G. D. (Ed.). The sources of entrepreneurial activity. Stanford, CA: JAI Press, 29-66.

Vázquez, J. L.; Georgiev, I.; Gutiérrez, P.; Lanero, A.; García, M. P. 2010a. Promoting regional development from university. Students' perceptions on entrepreneurship motivation and training programs, Trakia Journal of Sciences 8(1): 1-7.

Vázquez, J. L.; Lanero, A.; Gutiérrez, P.; García, M. P.; Alves, H.; Georgiev, I. 2010b. Entrepreneurship education in the university: does it make the difference?, Trakia Journal of Sciences 8(3): 64-70.

Vázquez, J. L.; Naghiu, A.; Gutiérrez, P.; Lanero, A.; García, M. P. 2009. Entrepreneurial potential in the University: intentions and attitudes towards new venture creation, Bulletin UASVM 66(2): 507-512.

Zabalda, M. A. 2009. La nueva misión académica, in Toledo, F.; Michavila, F. (Eds.). Empleo y nuevas titulaciones en Europa. Castellón: Tecnos Universitat Jaume I, 73-105.

José Luis VÁZQUEZ-BURGUETE (PhD, PhD HC) is a Titular Professor on Marketing in the Faculty of Economic and Management Sciences at Leon University, Spain; Holder of the Bancaja Chair on Young Entrepreneurship; President of the International Association on Public and Nonprofit Marketing (IAPNM/AIMPN).

Ana LANERO $(\mathrm{PhD})$ is a Research Assistant on Marketing and Market Research in the Faculty of Economic and Management Sciences at Leon University, Spain.

Agota Giedre RAISIENE (PhD) is an Associate Professor on Organizational Behaviour in the Faculty of Politics and Management at Mykolas Romeris University, Lithuania; President of the Academical Management and Administration Association.

María PURIFICACIÓN GARCÍA (PhD) is an Assistant Professor in the Faculty of Labor Sciences at Leon University, Spain. 